\title{
Identification of the Psychrophilic Histamine-Producing Marine Bacteria Previously Referred to as the N-group Bacteria
}

\author{
Tateo Fujii, ${ }^{* 1}$ Akira Hiraishi, ${ }^{* 2}$ Takeshi Kobayashi, ${ }^{* 1}$ \\ Rio Yoguchi, ${ }^{* 1}$ and Masayo Okuzumi, ${ }^{* 1, \dagger}$ \\ *1Department of Food Science and Technology, Tokyo University of Fisheries, \\ Konan, Minato, Tokyo 108, Japan \\ ${ }^{*}$ Laboratory of Environmental Biotechnology, Konishi Co., Ltd. \\ Yokokawa, Sumida, Tokyo 130, Japan
}

(Received December 27, 1996)

\begin{abstract}
The taxonomic position of the psychrophilic histamine-producing marine bacteria previously referred to as the $\mathrm{N}$-group bacteria, were studied phenotypically and genotypically. These strains were facultatively anaerobic Gram-negative asporogenous coccobacilli, which were motile by means of unsheathed polar flagella. They were also positive for $D$-glucose fermentation and poly- $\beta$-hydroxybutyrate accumulation, and had guanine plus cytosine contents of genomic DNA of 40 to $43 \mathrm{~mol} \%$. The N-group bacteria exhibited high levels of genomic DNA hybridization homology to the type strain of Photobacterium phosphoreum. The phenotypic and genotypic data suggested that the N-group bacteria are members of $P$. phosphoreum.
\end{abstract}

Key words: histamine, marine bacteria, Photobacterium phosphoreum

Histamine is generally found in spoiled scombroid fish and other marine fish that contain high levels of histidine in their muscle tissues, ${ }^{1}$ and is associated with the chemical intoxication called scombroid fish poisoning. Many workers isolated various histamine-producing bacteria from the fish which had been involved in food poisoning incidents. ${ }^{2)}$

Most of the histamine-producing bacteria isolated so far have been identified as being the members of the family Enterobacteriaceae..$^{2)}$ On the other hand, Okuzumi et al. ${ }^{3-10)}$ isolated two groups of histamine-producing marine bacteria with respect to growth temperatures. One of these groups included mesophiles for which we recently proposed to create a new species with the name Photobacterium histaminum sp. nov. ${ }^{3)}$ The other group included psychrophiles which grew well at $4^{\circ} \mathrm{C}$ but not at $40^{\circ} \mathrm{C}$ and were tentatively named the $\mathrm{N}$-group bacteria. ${ }^{4}$ ) While the ecological studies of the $\mathrm{N}$-group bacteria in marine fish $^{5,7,8)}$ and sea environment ${ }^{6)}$ have been made, the taxonomic position of these bacteria have not been studied in detail.

In the present report, we described the characterization and identification of the $\mathrm{N}$-group bacteria phenotypically and genotypically.

\section{Materials and Methods}

\section{Bacterial Strains}

Six histamine-producing strains which were isolated from marine fish and the sea water of Sagami Bay in Japan and have been previously referred to as the $\mathrm{N}$-group bacteria were used. Among them, strains N-XBO (from horse mackerel), N-KGF (from common mackerel) and N-VEF (from sea water) were luminous, and strains N-YAG (from sardine), N-MHL (from sea water) and N-611A (from saury pike) were nonluminous. Photobacterium phosphoreum ATCC $11040^{\mathrm{T}}, P$. leiognathi ATCC 25521 ${ }^{\mathrm{T}}$, P. angustum ATCC $25915^{\mathrm{T}}$ and $P$. histaminum $\mathrm{JCM} 8968^{\mathrm{T}}$ were used as the reference strains for DNA-DNA homology.

\section{Phenotypic Characterization}

Morphological, physiological and biochemical characteristics were studied as described previously. ${ }^{3)}$ Except where stated otherwise, cultivation temperature for the strains was $20^{\circ} \mathrm{C}$, and the media were prepared with 75 percent artificial sea water. ${ }^{11}$

\section{Genetic Properties}

Genomic DNA was isolated and purified in accordance with the method of Marmur, ${ }^{12)}$ and moles percent guanine plus cytosine $(\mathrm{G}+\mathrm{C})$ of DNA was determined by the HPLC method. ${ }^{13)}$ Experiments for DNA-DNA relatedness were carried out by the dot blot hybridization method with photobiotin labeling and colorimetric detection as described previously. ${ }^{14)}$

\section{Results}

The morphological, physiological and biochemical characteristics of the tested strains are shown in Table 1. They were Gram-negative asporogenous coccobacilli, $1.0 \sim 1.2$ $\mu \mathrm{m}$ in diameter and $2.0 \sim 2.2 \mu \mathrm{m}$ in length. These strains were motile by means of 1 to 3 polar flagella. Electron

\footnotetext{
† Present address: Natori Co. Ltd., Toshima, Kita, Tokyo 114, Japan.
} 
Table 1. Characteristics of the histamine-producing bacteria

\begin{tabular}{|c|c|c|}
\hline Characteristics & $\begin{array}{l}\text { Luminous } \\
3 \text { strains } \mathbf{s}^{\mathrm{a}}\end{array}$ & $\begin{array}{l}\text { Nonluminou } \\
3 \text { strains }\end{array}$ \\
\hline Gram stain & - & - \\
\hline Coccoid rod & + & + \\
\hline Spore & - & - \\
\hline Motility & + & + \\
\hline Sheathed polar flagella & - & - \\
\hline Acid from D-glucose & + & + \\
\hline Gas from D-glucose & + & + \\
\hline Catalase & + & + \\
\hline Oxidase & (1) & (2) \\
\hline Reduction of $\mathrm{NO}_{3}^{-}$to $\mathrm{NO}_{2}^{-}$ & + & + \\
\hline $\begin{array}{l}\text { Accumulation of PHB coupled } \\
\text { with the inability to utilize } \\
\beta \text {-hydroxybutyrate }\end{array}$ & + & + \\
\hline Production of 2,3-butanediol & + & + \\
\hline \multicolumn{3}{|l|}{ Hydrolysis of: } \\
\hline Starch & - & - \\
\hline Chitin & + & + \\
\hline Alginate & - & - \\
\hline Gelatin & - & - \\
\hline Lipase & - & - \\
\hline Luminescence & + & - \\
\hline Sensitivity to $0 / 129$ & + & + \\
\hline $\mathrm{Na}^{+}$required for growth & + & + \\
\hline \multicolumn{3}{|l|}{ Growth in $\mathrm{NaCl}$ : } \\
\hline $0 \%$ & - & - \\
\hline $2 \%$ & + & + \\
\hline $5 \%$ & + & + \\
\hline $7 \%$ & - & - \\
\hline \multicolumn{3}{|l|}{ Growth at: } \\
\hline $4^{\circ} \mathrm{C}$ & + & + \\
\hline $20^{\circ} \mathrm{C}$ & + & + \\
\hline $30^{\circ} \mathrm{C}$ & (1) & (1) \\
\hline $35^{\circ} \mathrm{C}$ & - & - \\
\hline \multicolumn{3}{|l|}{ Utilization of: } \\
\hline $\begin{array}{l}\text { D-ribose, D-fructose, D-glucose, } \\
\text { D-mannose, D-galactose, } \\
\text { Maltose, glycerol }\end{array}$ & + & + \\
\hline D-gluconate, $\mathrm{D}$-glucronate & + & - \\
\hline Pyruvate & (1) & (1) \\
\hline DL-glycerate & + & (1) \\
\hline Succinate, fumarate & (2) & (1) \\
\hline L-glutamate & (1) & + \\
\hline L-serine & (2) & (2) \\
\hline $\begin{array}{l}\text { Acetate, trehalose, L-proline, } \\
\text { Valerate, DL-malate, citrate, } \\
\text { D-xylose, L-arabinose, } \\
\text { L-rhamnose, lactose, salicine, } \\
\text { sucrose, D-mannitol, D-sorbitol, } \\
\text { ethanol, n-propanol, } \beta \text {-alanine, } \\
\text { L-leucine, L-citrulline, } \\
\text { L-histidine, L-ornithine, } \\
\text { betaine, cellobiose, melibiose }\end{array}$ & - & - \\
\hline $\mathrm{Mol} \% \mathrm{G}+\mathrm{C}$ in DNA & $41-42$ & $40-43$ \\
\hline
\end{tabular}

Strain N-XBO, N-KGF and N-VEF.

- Strain N-YAG, N-MHL and N-611A.

+ , all positive; - , all negative; ( ), No. of positive strains.

micrographs of negatively stained cells of the test strains showed that each fiagellum was about $15 \mathrm{~nm}$ thick and was not enclosed in a sheath. The colonies of the strains were convex, smooth with an entire edge and white in color on a complex medium. All of the strains grew well at $4^{\circ} \mathrm{C}$, but did not grow at $35^{\circ} \mathrm{C}$. They required $\mathrm{Na}^{+}$for growth and grew well in a medium containing $2 \% \mathrm{NaCl}$.
Table 2. Levels of DNA-DNA relatedness between the histamineproducing strains and three species in the genus Photobacteritum

\begin{tabular}{|c|c|c|}
\hline \multirow{2}{*}{ Source of unlabeled DNA } & \multicolumn{2}{|c|}{$\%$ Relatedness to labeled DNA from } \\
\hline & $\mathrm{N}-\mathrm{XBO}$ & N-YAG \\
\hline \multicolumn{3}{|l|}{$\begin{array}{l}\text { Histamine-producing } \\
\text { strains }\end{array}$} \\
\hline $\mathrm{N}-\mathrm{XBO}$ & 100 & NT \\
\hline N-YAG & NT & 100 \\
\hline $\begin{array}{c}\text { Photobacterium } \\
\text { phosphoreum } \\
\text { ATCC } 11040^{\mathrm{T}}\end{array}$ & 100 & 88 \\
\hline $\begin{array}{l}\text { Photobacterium } \\
\text { leiognathi } \\
\text { ATCC 25521 }\end{array}$ & 52 & 66 \\
\hline $\begin{array}{l}\text { Photobacterium } \\
\text { angustum } \\
\text { ATCC 25915 }\end{array}$ & 47 & 54 \\
\hline $\begin{array}{c}\text { Photobacterium } \\
\text { histaminum } \\
\text { JCM } 8968^{\mathrm{T}}\end{array}$ & 37 & 53 \\
\hline
\end{tabular}

NT, not tested.

They could grow neither in $0 \%$ nor $7 \% \mathrm{NaCl}$ broth. All of the strains fermentatively decomposed $\mathrm{D}$-glucose to gas and other acidic end products. They accumulated poly- $\beta$ hydroxybutyrate in the cells, but did not utilize exogenous monomer $\beta$-hydroxybutyrate. Acetoin and 2,3butanediol were produced from glucose. Lipase and gelatinase were not produced. The strains examined gave different reactions to the oxidase test. Strains N-YAG, NMHL and N-611A did not show luminescence. All of the strains grew in the mineral medium containing D-glucose, but not in the medium containing D-mannitol.

The DNA base composition was found to be 40 to 43 mol\% $\mathrm{G}+\mathrm{C}$ for the strains. The results of DNA-DNA hybridization with labeled DNAs from strains N-XBO and N-YAG are summarized in Table 2. P. phosphoreum ATCC $11040^{\mathrm{T}}$ exhibited high levels of homology with strain $\mathrm{N}-\mathrm{XBO}$ and with strain N-YAG, whereas the levels of DNA homology between these strains and $P$. leiognathi ATCC $25521^{\mathrm{T}}, P$, angustum ATCC $25915^{\mathrm{T}}$ and $P$. histaminum JCM $8968^{\mathrm{T}}$ were lower, less than $70 \%$.

\section{Discussion}

The strains which we examined were found to represent a very homogenous group of bacteria and thought to belong to a single species on the basis of the phenotypic characteristics. They were Gram-negative coccobacilli, motile by means of unsheathed polar flagella, endospore-negative, facultatively anaerobic, positive for D-glucose fermentation and poly- $\beta$-hydroxybutyrate accumulation. Also, the $\mathrm{G}+\mathrm{C}$ contents of DNA (mol\%) of them were 40 to 43 . It is considered that the N-group bacteria belong to genus Photobacterium in comparison with the properties of this genus described so far.

The genus Photobacterium now consists of five validly described species, $P$. phosphoreum, $P$. leiognathi, $P$. angustum, $P$. damsela and $P$. histaminum. The former three species were listed on the Bergey's Manual of Systematic 
Table 3. Characteristics for differentiating five species of genus Photobacterium

\begin{tabular}{|c|c|c|c|c|c|c|c|c|c|c|c|c|}
\hline \multirow{2}{*}{ Species } & \multirow{2}{*}{$\begin{array}{l}\text { Gas from } \\
\text { D-glucose }\end{array}$} & \multirow{2}{*}{$\begin{array}{l}\text { Biolumi- } \\
\text { nescence }\end{array}$} & \multirow{2}{*}{ Lipase } & \multirow{2}{*}{ Gelatinase } & \multicolumn{6}{|c|}{ Utilization of } & \multicolumn{2}{|c|}{ Growth at } \\
\hline & & & & & D-Xylose & Maltose & Acetate & DL-Glycerate & Pyruvate & L-proline & $4^{\circ} \mathrm{C}$ & $35^{\circ} \mathrm{C}$ \\
\hline \multicolumn{13}{|l|}{ The N-group bacteria } \\
\hline 3 luminous strains & + & + & - & - & - & + & - & + & (1) & - & + & - \\
\hline 3 nonluminous strains & + & - & - & - & - & + & - & (1) & (1) & - & + & - \\
\hline P. phosphoreum ${ }^{* 1}$ & + & + & - & - & - & + & - & + & - & - & + & - \\
\hline P. leiognathi ${ }^{* 1}$ & - & + & + & - & - & - & + & $\mathrm{D}$ & + & + & - & + \\
\hline$P$. angustum $^{* 1}$ & - & - & $\mathrm{D}$ & $\mathrm{D}$ & + & $\mathrm{D}$ & + & - & + & - & $\mathrm{D}$ & + \\
\hline P. damsela ${ }^{* 2}$ & $\mathrm{D}$ & - & + & - & - & ND & - & + & + & ND & - & + \\
\hline P. histaminum ${ }^{* 3}$ & + & - & $\mathrm{ND}$ & - & - & + & + & + & - & + & - & + \\
\hline
\end{tabular}

+, positive; -, negative; ( ), no. of positive strains; $D$, positive or negative; ND, no data.

* Data from Bergey's Manual of Systematic Bacteriology. ${ }^{15}$ )

*2 Data from Smith et al. 16

*3 Data from Okuzumi et al. ${ }^{3)}$

Bacteriology ${ }^{15)}$ in 1984, and under current taxonomic status another two species were added into genus Photobacterium.

Table 3 indicates characteristics for differentiating Photobacterium species quoted from the previous literatures. ${ }^{3,15-17)}$ The following combination of properties distinguishes $P$. phosphoreum from former species, $P$. leiognathi and $P$. angustum: production of gas from $\mathrm{D}$-glucose; no growth at $35^{\circ} \mathrm{C}$ and no assimulation of D-xylose, acetate, pyruvate and L-proline as the carbon source. Moreover, $P$. phosphoreum is positive for growth at $4^{\circ} \mathrm{C}$, luminescence and utilization of maltose and DL-glycerate and negative for production of gelatinase and lipase. ${ }^{15}$ ) Therefore, the six test strains are almost identical to $P$. phosphoreum in the phenotypic characteristics.

Recently two species of $P$. damsela ${ }^{16}$ and $P$. histaminum $^{3)}$ were added into genus Photobacterium. Listonella damsela (initially described as Vibrio damsela) was isolated from skin lesions on damselfish, and transferred into the genus Photobacterium as $P$. damsela. $P$. histaminum was histamine-producing marine bacteria. The $\mathrm{N}$-group bacteria differed from two new Photobacterium species in growth temperatures. Six test strains of the N-group bacteria grew well at $4^{\circ} \mathrm{C}$, even at $0^{\circ} \mathrm{C}$. But $P$. damsela could not grow at $4^{\circ} \mathrm{C}$ and grew much better at $25^{\circ} \mathrm{C}$ than $36^{\circ} \mathrm{C}$. $P$. histaminum was mesophiles which could not grow at $4^{\circ} \mathrm{C}$, and grew much better at $30^{\circ} \mathrm{C}$ and $35^{\circ} \mathrm{C}$.

Slight differences were apparent between the $\mathrm{N}$-group bacteria and $P$. phosphoreum. Different results of oxidase has been often obtained with the isolates of the N-group bacteria. ${ }^{4}$ Most of $P$. phosphoreum strain is oxidase negative $\left(10.1 \%\right.$ to $25 \%$ positive $\left.{ }^{17}\right)$, but Reichelt and Bau$\operatorname{mann}^{18)}$ showed that some strains of $P$. phosphoreum gave positive results when treated with toluene prior to the addition of the oxidase reagent. Therefore, it may appear that the diagnostic trait circumscribing for the genus Photobacterium does not include oxidase test.

There was variability in the ability to luminesce between the N-group bacteria. ${ }^{4}$ Strains N-XBO, N-KGF and NVEF were able to emit light of blue-green color, whereas strains N-YAG, N-MHL and N-611A do not. The ability to luminesce appears to be restricted to the species $P$. phosphoreum and $P$. leiognathi among members of the genus Photobacterium. ${ }^{15)}$ Therefore this character of latter three strains of the $\mathrm{N}$-group bacteria cannot coincide with that of $P$. phosphoreum. However, according to Baumann et $a{ }^{15)}$ strains of all luminous species develop dark mutants (nonluminous mutants) and may predominate under certain conditions. These facts suggest that nonluminous strains of the $\mathrm{N}$-group bacteria are nonluminous mutants of $P$. phosphoreum.

DNA-DNA hybridization data verify the taxonomic position of two strains, N-XBO (luminous strain) and $\mathrm{N}$ YAG (nonluminous strain) as being members of $P$. phosphoreum, and the high levels of homological similarity between the isolates and $P$. phosphoreum were observed. Consequently, they are phylogenetically closely related and it is considered that the $\mathrm{N}$-group bacteria fall into a single taxon and seem to be members of the species $P$. phosphoreum.

Besides our previous literatures on histamine-producing luminous bacteria, ${ }^{4-8)}$ Morii et al. reported that luminous bacteria produced histamine when scombroid fish was stored at low temperatures and these isolates belonged to $P$. phosphoreum on the basis of their phenotypical traits. ${ }^{19,20)}$ Nonluminous isolates of the $\mathrm{N}$-group bacteria were also identified as $P$. phosphoreum in this study. This fact indicated that $P$. phosphoreum should receive increased attention as histamine-producing marine bacteria.

\section{References}

1) A. Lukton and H. S. Olcott: Content of free imidazole compounds on the muscle tissue of aquatic animals. Food Res., 23, 611-618 (1958).

2) J. E. Stratton and S. L. Taylor: Scombroid poisoning, in "Microbiology of Marine Food Products", (ed. by D. R. Ward and C. R. Hackney), Van Nostrand Reinhold. New York, 1991, pp. 331-351.

3) M. Okuzumi, A. Hiraishi, T. Kobayashi, and T. Fujii: Photobacterium histaminum sp. nov., a histamine-producing marine bacterium. Int. J. Syst. Bacteriol., 44, 631-636 (1994).

4) M. Okuzumi, S. Okuda, and M. Awano: Isolation of psychrophilic and halophilic histamine-forming bacteria from Scomber japonicus. Nippon Suisan Gakkaishi, 47, 1591-1598 (1981).

5) M. Okuzumi, S. Okuda, and M. Awano: Occurrence of psychrophilic and halophilic histamine-forming bacteria ( $\mathrm{N}$-group bacteria) on/in red meat fish. Nippon Suisan Gakkaishi, 48, 799804 (1982).

6) M. Okuzumi and M. Awano: Seasonal variations in numbers of psychrophilic and halophilic histamine-forming bacteria ( $\mathrm{N}$-group bacteria) in seawater and on marine fishes. Nippon Suisan Gakkaishi, 49, 1285-1291 (1983). 
7) M. Okuzumi, H. Yamanaka, and T. Kubozuka: Occurrence of various histamine-forming bacteria on/in fresh fishes. Nippon Suisan Gakkaishi, 50, 161-167 (1984).

8) M. Okuzumi, H. Yamanaka, T. Kubozuka, H. Ozaki, and K. Matubara: Changes in numbers of histamine-forming bacteria on/ in common mackerel stored at various temperature. Nippon Suisan Gakkaishi, 50, 653-657 (1984).

9) R. Yoguchi, M. Okuzumi, and T. Fujii: Seasonal variation in numbers of mesophilic and halophilic histamine-forming bacteria in inshore of Tokyo Bay and Sagami Bay. Nippon Suisan Gakkaishi, 56, 1467-1472 (1990).

10) R. Yoguchi, M. Okuzumi, and T. Fujii: Seasonal variation in numbers of mesophilic and halophilic histamine-forming bacteria on marine fish. Nippon Suisan Gakkaishi, 56, 1473-1479 (1990).

11) W. J. Lyman and R. H. Fleming: Composition of seawater. J. Mar. Res., 3, 134-146 (1940).

12) J. Marmur: A procedure for the isolation of deoxyribonucleic acid from micro-organisms, J. Mol. Biol., 3, 208-218 (1961).

13) Y. Katayama-Fujimura, Y. Komatsu, and H. Kuraishi: Estimation of DNA base composition by high performance liquid chromatography of its nuclease $\mathrm{P} 1$ hydrolysate. Agric. Biol. Chem., 48, 3169-3172 (1984).

14) T. Ezaki, S. Dejsirilert, H. Yamamoto, N. Takeuchi, S. Liu, and E.
Yabuuchi: Simple and rapid genetic identification of Legionella species with photobiotin-labeled DNA. J. Gen. Appl. Microbiol, , 34, 191-199 (1988)

15) P. Baumann and L. Baumann: Genus Photobacterium, in "Bergey's Manual of Systematic Bacteriology", (ed. by N. R. Krieg and J. G. Holt), Williams and Wilkins, Baltimore, 1984, pp. 539-545.

16) S. K. Smith, D. C. Sutton, J. A. Fuerst, and L. Reichelt: Evaluation of the genus Listonella damsela (Love et al.) MacDonell and Colwell to the genus Photobacterium as Photobacterium damsela comb. nov. with an emended discription. Int. J. Syst. Bacteriol, 41, 529-534 (1994)

17) J. J. Falmer III and F. W. Hickman-Brenner: The Genera Vibrio and Photobacterium, in "The Prokaryotes. 2nd ed., Vol. III," (ed. by A. Balows, H. G. Trüper, M. Dworkin, W. Harder, and K-H. Schleifer), Springer-Verlag, New York, 1992. pp. 2952-3011.

18) J. L. Reichelt and $P$. Baumann: Taxonomy of the marine, luminous bacteria. Arch. Microbiol., 94, 283-330 (1973).

19) H. Morii, D. C. Cann, L. Y. Taylor, and C. K. Murray: Formation of histamine by luminous bacteria from scombroid fish. Nippon Suisan Gakhaishi, 52, 2135-2141 (1986).

20) H. Morii, D. C. Cann, and L. Y. Taylor: Histamine formation by luminous bacteria in mackerel stored at low temperatures. Nippon Suisan Gakkaishi, 54, 299-305 (1988). 